\title{
Effect of Elevated Carbon Dioxide and Temperature on Growth, Yield and Quality Parameters of Mulberry
}

\author{
C. Lavanya*, J. Ashoka, A.G. Sreenivasa, Sushila Nadagoud and B.V. Beladhadi \\ Department of Agricultural Entomology, University of Agricultural Sciences, \\ Raichur, Karnataka, India \\ *Corresponding author
}

\section{A B S T R A C T}

\begin{tabular}{|l|}
\hline Ke y w o r d s \\
$\mathrm{C}_{3}$, Elevated carbon \\
dioxide, Ambient \\
carbon dioxide, \\
C: $\mathrm{N}$ - carbon to \\
nitrogen ratio. \\
\hline Article Info \\
\hline Accepted: \\
26 September 2017 \\
Available Online: \\
10 November 2017 \\
\hline
\end{tabular}

Mulberry being a $\mathrm{C}_{3}$ crop responsive to carbon, climate change in the form of elevated $\mathrm{CO}_{2}$ coupled with increased temperature would be helpful for crop but it gets altered in presence of herbivore. The $\mathrm{eCO}_{2}$ and temperature favoured growth and development of mulberry only in terms of quantity which was evidenced by accelerated growth of more plant height, leaves, leaf area index, leaf yield and plant biomass. Biochemical analysis of mulberry showed a lot of changes in it, wherein, the chlorophyll, carbon and carbon based compounds viz., tannins, phenols, total sugars, carbohydrates significantly increased in $\mathrm{eCO}_{2}$ as compared to $\mathrm{aCO}_{2}$ treatments. On the contrary, nitrogen $(\mathrm{N})$ and $\mathrm{N}$ - based compounds viz., proteins decreased in $\mathrm{eCO}_{2}$ compounds which in turn altered $\mathrm{C}: \mathrm{N}$ ratio.

\section{Introduction}

Mulberry belongs to the family "Moraceae" under the genus "Morus" with several species. It thrives under varied climate ranging from temperate to tropical conditions and major mulberry growing areas of the globe is located north of the equator between $28{ }^{\circ} \mathrm{N}$ and $55^{\circ} \mathrm{N}$ latitude. The ideal range of temperature is from 24 to $28{ }^{\circ} \mathrm{C}$. Mulberry grows well in places with an annual rainfall ranging from 600 to $2500 \mathrm{~mm}$. In areas with low rainfall, growth is limited through moisture stress, resulting in low yields. On an average, mulberry requires $340 \mathrm{~m}^{3}$ per ha of water every ten days in case of loamy soils and 15 days in clayey soils. Atmospheric humidity range of 65-80 per cent is ideal for luxuriant mulberry growth. Sunshine is one of the important factors controlling growth and leaf quality. In the tropics, mulberry grows with a sunshine range of nine to 13 hours a day. Mulberry can be ideally cultivated up to an elevation of $1000 \mathrm{~m}$ above mean sea level. Mulberry leaves are highly palatable and digestible to mulberry silkworms and is the only satisfactory food plant. Protein content in the leaves and young stems, with a good essential amino acid profile, varying from 15 to 28 per cent depending on the variety. Mineral content is high with no antinutritional factors or toxic compounds have 
been identified. India is the second largest producer of silk in the world. Production of raw silk in India during the year 2013-14 has been 26,480 MT. Now, as a result of growing realization, sericulture is gaining ground in non-traditional areas too. The existence and prosperity of sericulture industry depends upon the production of quality silk. For production of quality cocoon and silk, silkworm larva should be fed with quality mulberry leaves, which is the exclusive food plant of the Bombyx mori $\mathrm{L}$.

\section{Materials and Methods}

An investigation was carried out to study the effect of elevated $\mathrm{CO}_{2}$ and temperature on growth, yield and quality parameters of mulberry under Open Top Chamber (OTC's) conditions and subsequent effect on mulberry silkworm at Main Agricultural Research Station (MARS), University of Agricultural Sciences, Raichur, Karnataka. The present study was carried out during kharif and rabi 2014-15 at MARS, Raichur, which is situated in the North Eastern Dry Zone (Zone-II) of Karnataka between $16^{\circ} 15^{\prime} \mathrm{N}$ latitude and $77^{\circ}$ $20^{\prime}$ E longitude with an altitude of $389 \mathrm{~m}$ above the mean sea level. The cement pots ( $2 \frac{1}{2}$ feet height with 2 feet diameter) were procured and filled with loamy soil and added with farm yard manure (FYM). Mulberry saplings which have been grown for a period of four months were uprooted from mulberry nursery and planted two saplings per cement pots allowed for establishment with proper watering and care as per treatment in OTC as well as in open plot. Plant growth parameters viz., time taken for sprouting, number of leaves per plant, number of shoots and plant height were recorded in one crop growth cycle. Also, leaf samples were collected on $65^{\text {th }}$ days of pruning for biochemical analysis. Organic carbon, leaf nitrogen, $\mathrm{C}: \mathrm{N}$ ratio, chlorophyll, flavonoids, tannins, phenols, morin were analyzed as per the standard procedure. The leaves from each plant were collected from each treatment and weighed at 65 DAP ad also shoot and root biomass was weighed by uprooting plants from the pot at last in order to know plant biomass. Leaf chlorophyll and flavonoids were measured using a Dualex Scientific sensor a hand tool leaf clip combining the use of fluorescence as well as light transmission of a leaf to determine its physiological status.

Nitrogen content in the plant sample was determined by using Micro-Kjeldahl technique, discovered by McKenzie (1994) and the per cent nitrogen was calculated by using the formula,

Titre value $\times$ Normality of $\mathrm{H}_{2} \mathrm{SO}_{4} \times 50$ $\%$ Nitrogen $=$ Weight of plant sample $\times 10$

Total organic carbon was estimated by dry combustion method / ash method using Muffle furnace.

$$
\text { Ash \% }=\frac{\left(\mathrm{W}_{3}-\mathrm{W}_{1}\right)}{\left(\mathrm{W}_{2}-\mathrm{W}_{1}\right)}
$$

Organic carbon $\%=(100-$ Ash \% $) \times 0.58(2)$

Where, $\mathrm{W}_{1}$ is weight of crucible, $\mathrm{W}_{2}$ is weight of oven-dried sample along with crucibles, and $\mathrm{W}_{3}$ is the weight of ash with crucibles and 0.58 is the conversion factor. Carbon to nitrogen ratio was analyzed by taking the ratio of carbon and nitrogen content readings previously obtained by estimation of the same. Tannins are polyphenolic compounds present in all types of plants. They were estimated by Folin -Dennis method (Malick and Singh, 1980) whereas, Phenols were estimated by Folin - Ciocalteau (FCR) method as suggested by Malick and Singh (1980). The method used for estimation of sugars was suggested by Nelson Somogyi 
(Marais et al., 1996) and for the estimation, alcohol was evaporated from the sample and was diluted appropriately. The aromatic amino acids present in a protein like tyrosine, tryptophan react with phosphomolybdo phosphor tungstate (FCR) reagent to produce a blue coloured complex at $660 \mathrm{~nm}$. The procedure for carbohydrates estimation was carried out as per AOAC (2005).

Carbohydra tes $(\%)=\frac{\mathrm{X}}{0.1} \times 100$

Where, $\mathrm{X}=$ Concentration of $\mathrm{D}$-glucose from standard graph. The crude fibre content in mulberry leaves was determined by sequential acid and alkali hydrolysis method (AOAC, 2005) using Fibra-Plus apparatus.

Crude fibre $(\%)=\frac{\mathrm{W}_{1}-\mathrm{W}_{2}}{\mathrm{~W}} \times 100$

\section{Results and Discussion}

Carbon dioxide is the most studied greenhouse gas in climate change research and the impact of elevated greenhouse gas concentrations on the performance of plants and herbivores has been well documented (Lindroth, 2010). The effect of elevated $\mathrm{CO}_{2}$ and temperature on mulberry has direct effect on growth, development, nutritional status and yield of mulberry. The leaves and plant height showed significant increase in elevated $\mathrm{CO}_{2}$ conditions over the cropping period. At $60 \mathrm{DAP}$, thee $\mathrm{CO}_{2}(550 \mathrm{ppm} \pm 25 \mathrm{ppm})$ alone treatment recorded maximum plant height (70.33 and $93.74 \mathrm{~cm}$ ) and more number of leaves (247.33 and 350.00 leaves/ plant). The growth parameters of mulberry are well supported by earlier studies by Nereu (2005), Mirwais and David (2011) and Attipalli et al., (2010) according to them plants/ crops exhibited increased growth rates in elevated
$\mathrm{CO}_{2}$ treatment conditions. And also the leaf yield and total plant biomass were highest in elevated $\mathrm{CO}_{2}(550 \mathrm{ppm} \pm 25 \mathrm{ppm})$ treatment $701.17 \mathrm{~g} /$ plant and $1026.28 \mathrm{~g} /$ plant, respectively. The results of the present study are in line with earlier findings of Thomas and Luit (1996) and they reported 56 per cent increased total shoot biomass in Arabidopsis thaliana L. Similarly the leaf are index, nitrogen biased index and chlorophyll was also found to be significantly highest in $\mathrm{eCO}_{2}$ alone $\left(2.09 \mu / \mathrm{cm}^{2}, 28.51 \mu / \mathrm{cm}^{2}\right.$ and $36.61 \mu /$ $\mathrm{cm}^{2}$ ) respectively.

The $\mathrm{eCO}_{2}$ has positively influenced the growth indices viz., leaf area index, nitrogen balanced index and the earlier studies of Nereu (2005) reported increased growth rates by $\mathrm{C}_{3}$ plants under $\mathrm{eCO}_{2}$ conditions and mulberry being $\mathrm{C}_{3}$ plant in the present study responded positively to $\mathrm{CO}_{2}$. Further, the direct effects of $\mathrm{eCO}_{2}$ on individual plant species have been well documented (Curtis and Wang, 1998) wherein, $\mathrm{eCO}_{2}$ generally resulted in increased leaf area index and increased growth rate and the rise in chlorophyll content in the elevated climate change treatments was because of that the plant chlorophyll content increased with increased $\mathrm{CO}_{2}$ concentration exposure, especially in $\mathrm{C}_{3}$ plants, (Hamid et al., 2012). Whereas, the flavonoid content was significantly highest in reference plot compared to elevated conditions $\left(1.53 \mu / \mathrm{cm}^{2}\right)$ (Table 1). Ambient $\mathrm{CO}_{2}$ treatments recorded higher nitrogen percentage wherein, the leaves from reference plot recorded higher values $(3.93 \mathrm{mg} / \mathrm{g}$ ) at $60 \mathrm{DAP}$. Further, carbon percentage recorded in the $\mathrm{eCO}_{2}$ treatments was higher $(25.67 \mathrm{mg} / \mathrm{g})$ over $\mathrm{aCO}_{2}$ treatments at 60 DAP. Furthermore, with increased carbon and decreased nitrogen, the $\mathrm{C}$ : $\mathrm{N}$ ratio increased $(8.89 \mathrm{mg} / \mathrm{g})$ in the $\mathrm{eCO}_{2}$ treatments as compared to $\mathrm{aCO}_{2}$ treatments at 60 days after pruning. 
Table.1 Effect of $\mathrm{eCO}_{2}$ and temperature on growth and yield parameters of mulberry

\begin{tabular}{|c|c|c|c|c|c|c|c|c|}
\hline Treatment & $\begin{array}{c}\text { Plant } \\
\text { height } \\
(\mathrm{cm})\end{array}$ & $\begin{array}{c}\text { No. of } \\
\text { leaves } \\
\text { (No.) }\end{array}$ & $\begin{array}{c}\text { Leaf } \\
\text { yield } \\
(\mathrm{g}) \\
\end{array}$ & $\begin{array}{c}\text { Plant } \\
\text { biomass } \\
(\mathrm{g}) \\
\end{array}$ & $\underset{\left(\mu / \mathbf{c m}^{2}\right)}{\mathbf{L A I}}$ & $\begin{array}{c}\text { NBI } \\
\left(\mu / \mathbf{c m}^{2}\right)\end{array}$ & $\begin{array}{l}\text { Chlorophyll } \\
\qquad\left(\mu / \mathbf{c m}^{2}\right)\end{array}$ & $\begin{array}{c}\text { Flavonoid } \\
\left(\mu / \mathbf{c m}^{2}\right)\end{array}$ \\
\hline $\mathrm{eCO}_{2}(550 \mathrm{ppm})$ & 93.74 & 350.00 & 701.17 & 1026.28 & 2.09 & 26.21 & 36.61 & 1.24 \\
\hline $\begin{array}{l}\mathrm{eCO}_{2}+\mathrm{eTemp} \\
\left(550 \mathrm{ppm}+2^{0} \mathrm{C}\right)\end{array}$ & 95.11 & 331.66 & 657.83 & 935.50 & 1.98 & 28.51 & 35.38 & 1.07 \\
\hline $\begin{array}{l}\mathrm{aCO}_{2}+\mathrm{eTemp} \\
\left(390 \mathrm{ppm}+2^{0} \mathrm{C}\right)\end{array}$ & 91.02 & 312.00 & 663.00 & 900.77 & 1.62 & 25.23 & 35.60 & 1.05 \\
\hline $\begin{array}{l}\mathrm{aCO}_{2} \\
\mathrm{ppm})\end{array}$ & 92.98 & 324.94 & 630.00 & 947.614 & 1.90 & 22.65 & 35.13 & 1.46 \\
\hline Reference Plot & 91.55 & 319.00 & 627.33 & 947.38 & 1.81 & 20.65 & 34.70 & 1.53 \\
\hline $\mathrm{CV}(\%)$ & 0.85 & 0.93 & 4.12 & 2.18 & 3.30 & 1.54 & 0.58 & 1.35 \\
\hline $\mathrm{S} . \mathrm{Em} \pm$ & 0.39 & 1.50 & 13.52 & 10.40 & 0.03 & 0.19 & 0.10 & 0.01 \\
\hline CD@0.01 & 1.21 & 6.60 & 58.4 & 44.95 & 0.13 & 0.82 & 0.44 & 0.04 \\
\hline
\end{tabular}

Table.2 Effect of elevated $\mathrm{CO}_{2}$ and temperature on phytochemistry of mulberry

\begin{tabular}{|l|c|c|c|c|c|c|c|c|c|}
\hline Treatment & $\begin{array}{c}\text { Leaf } \\
\text { nitrogen } \\
(\mathbf{m g} / \mathbf{g})\end{array}$ & $\begin{array}{c}\text { Leaf } \\
\text { carbon } \\
(\mathbf{m g} / \mathbf{g})\end{array}$ & $\begin{array}{c}\text { C:N } \\
(\mathbf{m g} / \mathbf{g})\end{array}$ & $\begin{array}{c}\text { Tannin } \\
(\mathbf{m g} / \mathbf{g})\end{array}$ & $\begin{array}{c}\text { Phenol } \\
(\mathbf{m g} / \mathbf{g})\end{array}$ & $\begin{array}{c}\text { Total } \\
\text { sugars } \\
(\mathbf{m g} / \mathbf{g})\end{array}$ & $\begin{array}{c}\text { CHO } \\
(\mathbf{m g} / \mathbf{g})\end{array}$ & $\begin{array}{c}\text { Proteins } \\
(\mathbf{m g} / \mathbf{g})\end{array}$ & $\begin{array}{c}\text { Crude } \\
\text { fibre } \\
(\mathbf{m g} / \mathbf{g})\end{array}$ \\
\hline $\mathrm{eCO}_{2}(550 \mathrm{ppm})$ & 3.08 & 23.54 & 7.66 & 1.91 & 4.19 & 13.08 & 5.26 & 5.39 & 7.87 \\
\hline $\begin{array}{l}\mathrm{eCO}_{2}+\mathrm{eTemp} . \\
\left(550 \mathrm{ppm}+2^{0} \mathrm{C}\right)\end{array}$ & 2.94 & 25.67 & 8.89 & 1.52 & 4.09 & 12.9 & 5.18 & 4.82 & 7.5 \\
\hline $\begin{array}{l}\mathrm{aCO}_{2}+\mathrm{eTemp} \\
\left(390 \mathrm{ppm}+2^{0} \mathrm{C}\right)\end{array}$ & 3.27 & 22.7 & 6.96 & 1.17 & 3.09 & 12.13 & 4.84 & 5.44 & 6.9 \\
\hline aCO $(390 \mathrm{ppm})$ & 3.83 & 22.5 & 5.91 & 1.07 & 3.26 & 12 & 4.91 & 6.12 & 6.33 \\
\hline Reference Plot & 3.93 & 21.25 & 5.45 & 0.98 & 3.39 & 11.89 & 5.15 & 6.24 & 6.18 \\
\hline $\mathrm{CV}(\%)$ & $\mathbf{1 . 0 1}$ & $\mathbf{0 . 3 2}$ & $\mathbf{1 . 2 7}$ & $\mathbf{2 . 7 3}$ & $\mathbf{0 . 9 2}$ & $\mathbf{2 . 5 2}$ & $\mathbf{0 . 5 8}$ & $\mathbf{2 . 0 7}$ & $\mathbf{2 . 4 7}$ \\
\hline S.Em \pm & $\mathbf{0 . 0 2}$ & $\mathbf{0 . 0 4}$ & $\mathbf{0 . 0 4}$ & $\mathbf{0 . 0 2}$ & $\mathbf{0 . 0 2}$ & $\mathbf{0 . 1 6}$ & $\mathbf{0 . 0 2}$ & $\mathbf{0 . 0 6}$ & $\mathbf{0 . 0 9}$ \\
\hline $\mathrm{CD}$ @ 0.01 & $\mathbf{0 . 0 7}$ & $\mathbf{0 . 1 6}$ & $\mathbf{0 . 1 9}$ & $\mathbf{0 . 0 8}$ & $\mathbf{0 . 0 7}$ & $\mathbf{0 . 6 8}$ & $\mathbf{0 . 0 8}$ & $\mathbf{0 . 2 5}$ & $\mathbf{0 . 3 7}$ \\
\hline
\end{tabular}

It is well known that the direct effect of enriched atmospheric $\mathrm{CO}_{2}$ on plant growth, physiology and community structure is depicted by increased plant growth by accelerating rates of photosynthesis, which reduced tissue quality and increased the carbon to nitrogen $(\mathrm{C}: \mathrm{N})$ ratio (Robinson et al., 2010). Elevated $\mathrm{CO}_{2}$ conditions has promoted increased biomass production with reduced foliar nitrogen and increased $\mathrm{C}: \mathrm{N}$ ratio for most plants, especially $\mathrm{C}_{3}$ crops
(Chen et al., 2005). Tannins and phenols content were significantly higher in $\mathrm{eCO}_{2}$ treatments over $\mathrm{aCO}_{2}$ treatments. Highest tannins $(1.91 \mathrm{mg} / \mathrm{g})$ and phenols $(4.19 \mathrm{mg} / \mathrm{g})$ were recorded in $\mathrm{eCO}_{2}(550 \mathrm{ppm} \pm 25 \mathrm{ppm})$. The present findings with respect to tannins and phenols revealed that elevated conditions favoured plant defensive chemicals wherein, highest values of tannins and phenols were found in the elevated treatments as compared to ambient levels. Since, tannins and phenols 
are carbon based compounds, along with increased carbon; these compounds have also increased in the elevated climate change treatments. The current findings are in line with earlier studies of Xiaowei et al., (2008) who reported that some kinds of defensive secondary compounds such as phenolics tend to increase in the $\mathrm{eCO}_{2}$ conditions. The total sugars were significantly highest in $\mathrm{eCO}_{2}$ $(550 \mathrm{ppm})$ treatment $(13.08 \mathrm{mg} / \mathrm{g})$ at 60 DAP. The present findings are in line with earlier studies by Xin et al., (2013) who reported that $\mathrm{eCO}_{2}$ conditions favoured increased carbohydrates accumulation in tomato plants. Further, the leaf carbohydrate determinations showed that the starch, total sugars and sucrose concentration increased significantly in plants exposed to $\mathrm{eCO}_{2}$ conditions. Elevated $\mathrm{CO}_{2}$ treatments recorded lower protein levels $(4.82 \mathrm{mg} / \mathrm{g})$ at $60 \mathrm{DAP}$ whereas, the carbohydrate content was significantly maximum in $\mathrm{eCO}_{2}(550 \pm 25$ $\mathrm{ppm})$ treatment $(5.26 \mathrm{mg} / \mathrm{g})$ at $60 \mathrm{DAP}$. The carbohydrate content was lower in $\mathrm{aCO}_{2}$ treatments in comparison with $\mathrm{eCO}_{2}$ treatment (Table 2). Contrary to this, protein production in mulberry was higher in $\mathrm{aCO}_{2}$ treatment is in line with the reports of Yin et al., (2010) according to them atmospheric $\mathrm{CO}_{2}$ enrichment induced changes in phytochemistry of maize plant with decreased protein. Further, the present investigations showed that soluble proteins and carbohydrates had a significant negative effect of $\mathrm{eCO}_{2}$ and temperature.

\section{References}

AOAC, Association of Official Analytical Chemists, 2005, J. Association of Official Agri. Chemists., 80: 725.

Attipalli, R. R., Girish, K. R. and Agepati, S. R., 2010. The impact of global elevated $\mathrm{CO}_{2}$ concentration on photosynthesis and plant productivity. Department of Plant Sciences, Curr. Sci., 98: 1305-
1319.

Curtis, P. S., and Wang, X., 1998, A metaanalysis of elevated $\mathrm{CO} 2$ effects on woody plant mass, form and physiology, Oecol., 113: 299-313.

David, N. K., and Christopher, G., 2011, Elevated $\mathrm{CO}_{2}$ increases constitutive phenolics and trichomes, but decreases inducibility of phenolics in Brassica rapa (Brassicaceae). J. Chem. Ecol., 37: 1332-1340.

Hamid. R. M., Ahmad, R. and Bagheri, A. R., 2012. The impact of elevated $\mathrm{CO}_{2}$ on growth and competitiveness of $\mathrm{C}_{3}$ and $\mathrm{C}_{4}$ crops and weeds. Eur. J. Exp. Biol., 2(4): 1144-1150.

Lindroth, R. L., 2010, Impacts of elevated atmospheric $\mathrm{CO}_{2}$ and $\mathrm{O}_{3}$ on forests: phytochemistry, trophic interactions and ecosystem dynamics. J. Chem. Ecol., 36: 2-21.

Malick, E. P., and Singh, M. B., 1980, Plant enzymology and hittoenzymology. Kalyani Publishers, New Delhi, p. 286.

Marais, J.P., Wilt, J. L and Quicke, G. V., 1986. A critical examination of the Nelson Somogyi method for the determination of reducing sugars. Anal. Biochem, 15(3): 373-381.

Mckenzie, H. A., 1994, The Kjeldhal determination of nitrogen: retrospect and prospect. Anal. Chem., 13(14): 138.

Mirwais, M. Q., and David, M. R., 2009, Crop responses to elevated carbon dioxide and temperature. Department of biological sciences, Climate Change and Crops, Environ Sci and Eng., 3: 540-88.

Nereu, A. S., 2005, Climate change and agroecosystems: the effect of elevated atmospheric $\mathrm{CO}_{2}$ and temperature on crop growth, development, and yield. Ciencias. Rurais, 35: 730-740.

Phoungchandang, S., Tochip, L. and Srijesdaruk, V., 2008, White mulberry leaf drying by tray and heat pump 
dehumidified dryers, World. J. Agric. Sci, 4: 844-851.

Robinson, E. A., Ryon, G. D. and Newman, J. A., 2012. A meta-analytical review of the effects of elevated $\mathrm{CO}_{2}$ on plantarthropod interactions highlights the importance of interacting environmental and biological variables, New Phytol., 194: 321-336.

Thomas, A. W. V., and Luit, J. D. K., 1996, Impact of elevated $\mathrm{CO}_{2}$ on growth and development of Arabidopsis thaliana L., Department of Genetics, University of Groningen, download under www.biologiezentrum.at

Xiaowei, W., Lanzhu, J. I., Guiqing, W. and
Yan, L., 2008, Potential effects of elevated $\mathrm{CO}_{2}$ on leaf-feeding forest insects. Chinese. J. Appl. Ecol., 3(1): 68-77.

Xin, L., Zhang, G., Sun, B., Zhang, S., Zhang, Y., Liao, Y., Zhou, Y., Xia, X., Shi, K. and Jingaquan, Y., 2013, Stimulated leaf dark respiration in tomato in an elevated carbon dioxide atmosphere. Sci. Rep., pp. 3433.

Yin, J., Cheng, S., Gang, W. and Feng, G., 2010, Effects of elevated $\mathrm{CO}_{2}$ associated with maize on multiple generations of the cotton bollworm, Helicoverpa armigera. Entomol. Exp. Appl., 136(1): 12-20.

\section{How to cite this article:}

Lavanya, C., J. Ashoka, A.G. Sreenivasa, Sushila Nadagoud and Beladhadi, B.V. 2017. Effect of Elevated Carbon Dioxide and Temperature on Growth, Yield and Quality Parameters of Mulberry. Int.J.Curr.Microbiol.App.Sci. 6(11): 3351-3356.

doi: https://doi.org/10.20546/ijcmas.2017.611.393 